\title{
ASSESSMENT OF THE NUTRITIONAL STATUS OF CANDIDATES TO THE AVIATION HIGH SCHOOL IN DĘBLIN
}

\author{
Agata GAŹDZIŃSKA', Marta TURCZYŃSKA', Paweł JAGIELSKI² \\ 1 Laboratory of Dietetics and Obesity Treatment, Department of Psychophysiological Measurements and \\ Human Factor Research, Military Institute of Aviation Medicine, Warsaw, Poland \\ 2 Department of Nutrition and Drug Research, Faculty of Health Science, Jagiellonian University, Medical \\ College, Cracow, Poland
}

Source of support: Own sources

Author's address: A. Gaździńska, Military Institute of Aviation Medicine, Krasińskiego 54/56 Street, 01-755 Warsaw, Poland, e-mail: agazdzinska@wiml.waw.pl

Introduction: The aim of the study was to assess the nutritional status of candidates to the General Aviation High School in Dęblin using selected anthropometric indices and bioelectrical impedance analysis.

Methods: Methods: A total of 103 candidates to the General Aviation High School in Dęblin (88 boys and 15 girls) participated in the study. The mean age of the participants was $14.7 \pm 0.46$ years. The nutritional status was assessed based on measurements of body weight, body height, and calculated BMI. The results were interpreted using growth charts. The body composition was determined by means of the bioelectrical impedance

Results: method.

Mean BMl of the girls was $20.6 \pm 3.0 \mathrm{~kg} / \mathrm{m} 2$ (16.3 to $26.2 \mathrm{~kg} / \mathrm{m} 2$ ) and of the boys $20.1 \pm 2.5$ $\mathrm{kg} / \mathrm{m} 2$ (14.4 to $27.8 \mathrm{~kg} / \mathrm{m} 2)$. Most of the examined adolescents ( $73.3 \%$ of girls and $75 \%$ of boys) had normal body weight. There were no significant differences in nutritional status in relation to the gender of the participants. 3.4\% of the boys were found to be underweight. None of the girls showed features of malnutrition. Overweight, according to $\mathrm{BMI}$, was diagnosed in $13.3 \%$ of the girls and $10.2 \%$ of the boys, obesity in $6.7 \%$ of the girls and $1.1 \%$ of the boys. Too low body fat percentage was observed in almost half of the boys examined.

Figures: 3 - Tables: 1 - References: 23 - Full-text PDF: http://www.pjambp.com • Copyright @ 2021 Polish Aviation Medicine Society, ul. Krasińskiego 54/56, 01-755 Warsaw, license WIML • Indexation: Index Copernicus, Polish Ministry of Science and Higher Education 
Conclusions: The majority of the General Aviation High School candidates examined were of normal body weight. No significant differences were noted between the nutritional status and the gender of the participants, based on BMI. Overweight and obesity diagnosed on the basis of body fat percentage was significantly more frequent in the group of girls. There is a need to educate youth about the health consequences of abnormal body weight, both underweight and overweight.

Keywords: nutritional status, BMI, children, aviation high school candidates, obesity

\section{INTRODUCTION}

The General Aviation High School (Pol. Ogólnokształcące Liceum Lotnicze - OLL) is a post-primary school with a four-year educational cycle, educating youth with specific psychophysical characteristics to be candidates to study at Military University of Aviation (Pol. Lotnicza Akademia Wojskowa - LAW) in Dęblin. The main aim of the school is to prepare students for future service as pilots - officers of the Polish Armed Forces. The psychophysical abilities of candidates to undertake education in the OLL are verified by tests conducted at the Military Institute of Aviation Medicine in Warsaw (Pol. Wojskowy Instytut Medycyny Lotniczej - WIML). The school provides additional classes covering aviation knowledge and skills as well as such subjects as modeling, aviation history, avionics, and aircraft construction and operation. The OLL students have the opportunity to participate in aviation training, the theoretical part of which takes place during the school year, and the practical part at the airport during summer vacations. They then perform parachute jumps and receive glider training. Following the matriculation examination and being given the appropriate medical fitness category, the graduates take selective aircraft training before entering LAW. The vast majority of OLL graduates enroll at LAW or other military universities.

In the 2020/2021 school year at the OLL there were 54 candidates admitted to the 1st grade, of whom 5 were girls. Candidates to the OLL must meet numerous criteria during the recruitment process. These include having Polish citizenship. They must not be 16 years old in the qualifying year. They must present a certificate of fitness for studying at the OLL, issued by the Medical Recruitment Committee of the Aeronautical and Occupational Medicine Certification Center at WIML. It is also necessary to have a certificate of the 8th grade examination results and physical fitness tests.
A dynamic increase in the number of obese people, also among children and adolescents, has been observed worldwide in recent years [7]. According to WHO [21], the main cause of excessive body weight is an imbalance between the energy intake and its expenditure. Environmental and psychological factors also play an important role in the pathogenesis of obesity $[4,5,23]$. Assessment of the nutritional status of the organism, allowing to identify nutritional deficiencies or excesses, is particularly important during adolescence due to the intensive growth and development of the organism [19].

OLL candidates must have correct health condition indices, including the nutritional status. To our knowledge, so far no one has analyzed the assessment of nutritional status of candidates to the Aviation High School in Dęblin, which became the aim of this study.

\section{METHODS}

A total of 103 candidates to the General Aviation High School in Dęblin took part in the study, of which 88 were boys and 15 were girls. They were persons attending obligatory anthropometric measurements in the Laboratory of Dietetics and Obesity Treatment at WIML, as a part of OLL qualification tests. The mean age of the participants was $14.7 \pm 0.46$ years.

After obtaining consent from the guardians, the nutritional status of the examined group was assessed. Measurements of current body weight and height were used for this purpose. The collected data were used to calculate and then interpret their BMI values. BMI was calculated by dividing the body weight given in kilograms by the square of body height in meters.

Using a bioelectrical impedance (BIA) body composition analyzer (Inbody 270, Japan), the participants' body fat mass, skeletal muscle mass, and total body water volume were determined. 
In order to compare the obtained results of body fat content the reference values for Caucasian children and adolescents, taking into account the gender, were used [15]. Interpretation of total body water content was based on the manufacturer's recommendations, for individuals under 18 years of age.

The body height was measured with an anthropometer (Holtain, the UK) with an accuracy of $1 \mathrm{~mm}$, in a standing upright position, without shoes. The body weight and body composition were measured in the participants wearing only underwear, after bladder emptying.

The assessment of BMI was based on the height and weight and growth charts developed by Kułaga et al. and the body mass to height ratio of children and adolescents in Poland - the results of the OLAF study [12].

The BMI interpretation adopted cut-off points for the population of children and adolescents in Poland, i.e. <5th centile: underweight, 5-15th: at risk of underweight, 15-85th centile: normal body weight, $\geq 85$ th centile: overweight, and obesity was diagnosed when BMI was $\geq 95$ th centile[10].

Tall stature was diagnosed in children with body height above the 97th centile, and short stature below the 10th centile for their respective age and gender.

The obtained results were compiled in MS Excel and subjected to statistical analysis in the PS IMAGO PRO software (IBM SPSS Statistics 25) by calculating the mean value, median, minimum, maximum, standard deviation. In order to verify the differences in the interpretation of nutritional status, body height and body fat level with re- spect to gender, the Mann-Whitney $U$ test and the chi-square test were used. The level of statistical significance was assumed to be $a<0.05$. The study was conducted from February to July 2020.

\section{RESULTS}

Mean BMI of the girls was $20.6 \pm 3.0 \mathrm{~kg} / \mathrm{m}^{2}(16.3$ to $26.2 \mathrm{~kg} / \mathrm{m}^{2}$ ) and of the boys $20.1 \pm 2.5 \mathrm{~kg} / \mathrm{m}^{2}$ $\left(14.4\right.$ to $\left.27.8 \mathrm{~kg} / \mathrm{m}^{2}\right)$. Among both girls and boys, a higher mean value of this parameter was recorded in 15-year-olds as compared to 14-yearolds (table 1). The interpretation BMI in relation to growth charts revealed that most of the examined adolescents (74.8\%; of which $73.3 \%$ were girls and $75 \%$ were boys) had a normal body weight (fig. 1). There were no significant differences between the genders of the participants in this regard. 3.4\% of the boys were found to be underweight. None of the girls showed features of malnutrition.

Most of the OLL candidates, irrespective of gender, were characterized by body height within the normal range. $2.3 \%$ of the boys were shortstatured (values below the 10th centile), and about $7 \%$ of the girls were tall-statured (values above the 97th centile) (fig. 2).

The mean body fat content of the girls examined was $24.2 \pm 7.5 \%$, ranging from $11.4 \%$ to $40.7 \%$. In contrast, the mean body fat content of the boys in the study was $11.7 \pm 5.4 \%$, ranging from $3 \%$ to $26.1 \%$. Overweight and obesity diagnosed on the basis of body fat percentage was significantly more common in the girls' group $(p<0.05)$. Excessive level of body fat was found in $20 \%$ of the female candidates (fig.3). In the group of boys, no

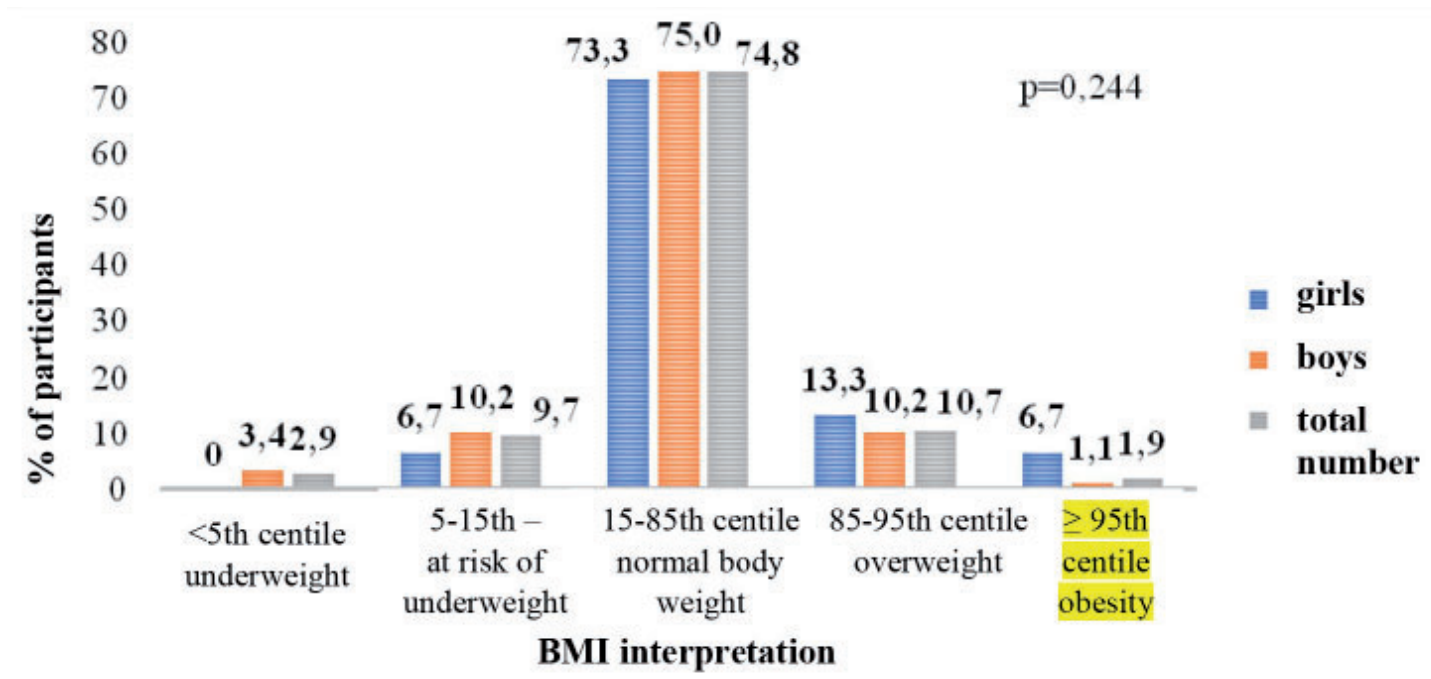

Fig. 1. Nutritional status of the OLL candidates based on BMI by gender. 


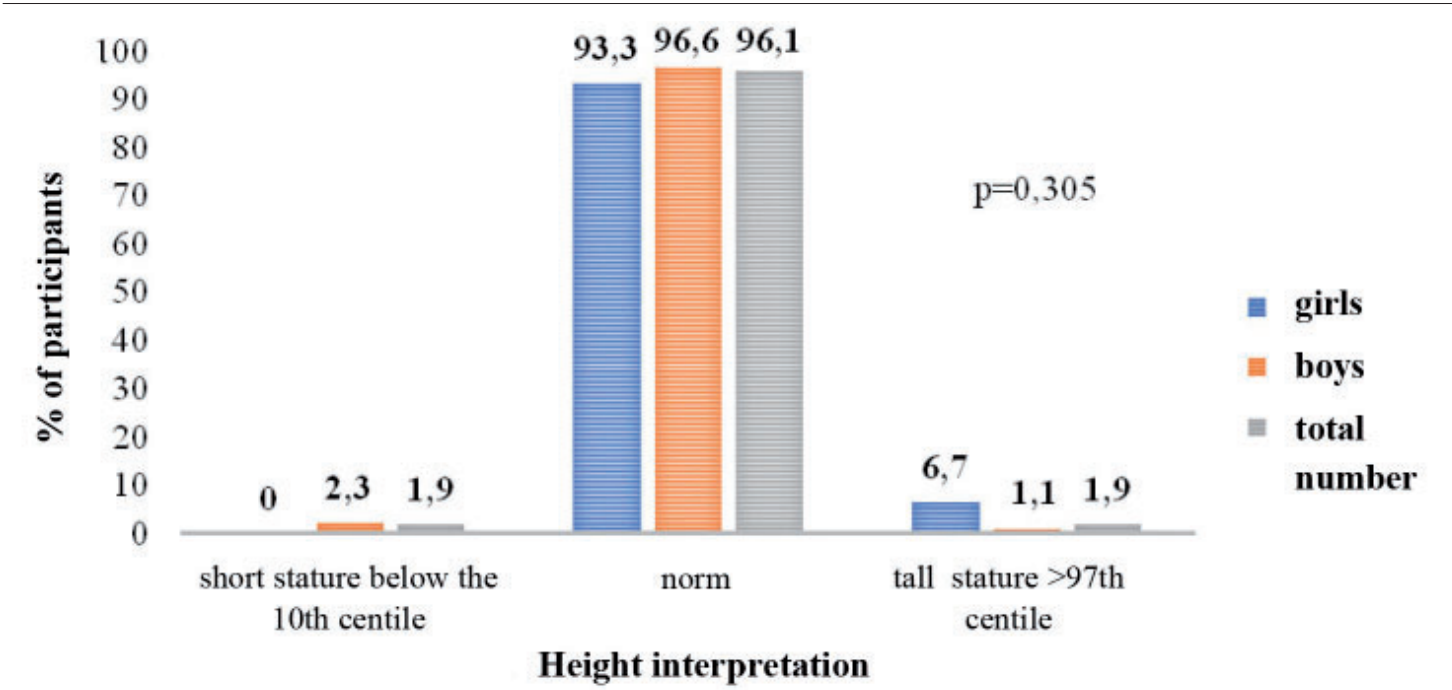

Fig. 2. Percentage of short-statured, normal height, and tall-statured individuals among the OLL candidates according to growth charts, by gender.

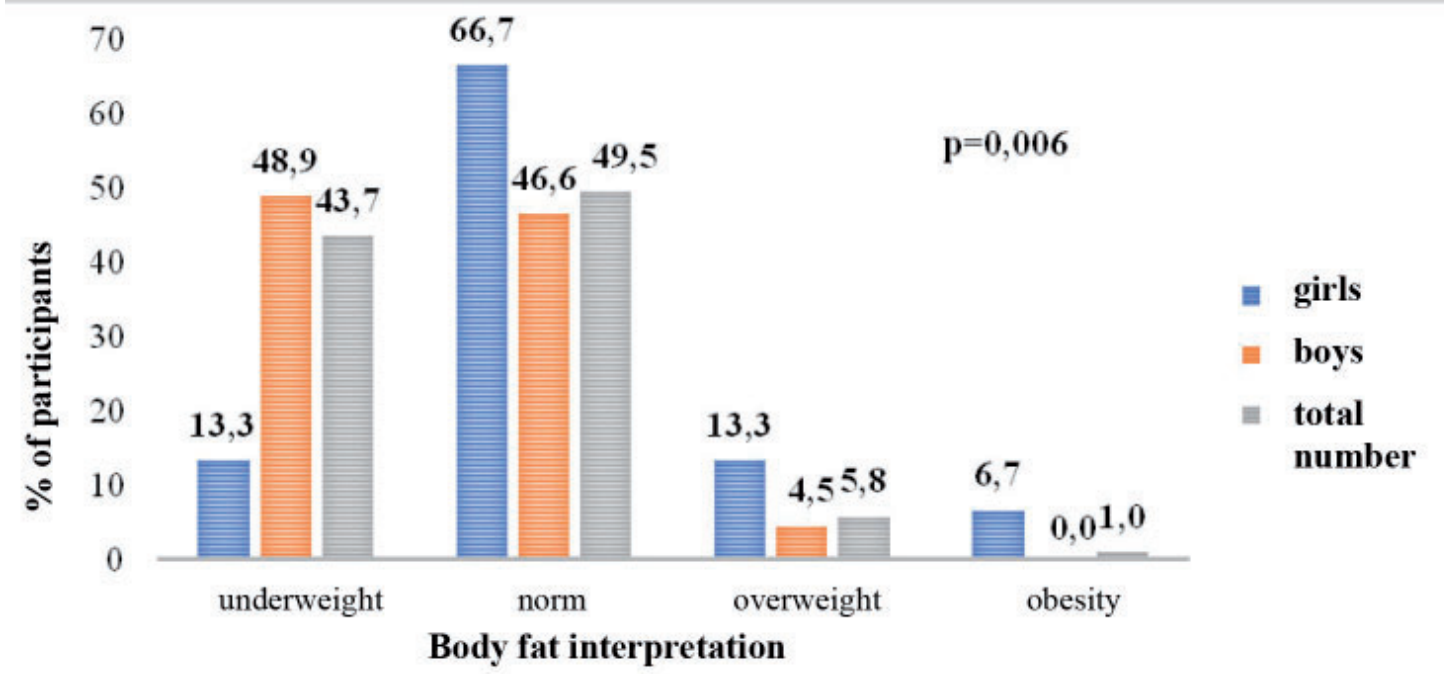

Fig. 3. Nutritional status of the OLL candidates based on body fat percentage, by gender.

individuals with body fat content suggesting obesity were observed, but excessively low body fat was noted in almost half of the participants.

The results of measurements of total body water content and skeletal muscle mass by age and gender are presented in table 1.

\section{DISCUSSION}

The assessment of the nutritional status of children and adolescents in Poland, based on the literature from 10 years (2005-2015), presented in the work of Malczyk [14] revealed significant irregularities in the nutritional status of children and adolescents. Underweight was observed in an average of $3 \%$ to $18 \%$ of boys, and up to $20 \%$ of girls. The percentage of children and adolescents with overweight oscillated around $12-15 \%$ and with obesity - around $5-11 \%$. Despite gaining more and more knowledge about the risk factors in the development of nutritional status disorders, as well as other chronic NCDs, the percentage continues to increase. This is especially true for children during puberty.

Overweight and obesity in childhood entail many potential health risks, leading to both earlylife complications and those emerging in adulthood $[3,17]$. Accumulation of fat tissue increases the risk of developing the metabolic syndrome, with all its consequences, already in early adolescence $[1,13]$. Furthermore, Kasley et al. [6] prove that health consequences may still be present despite normalization of body weight in a person burdened with obesity in childhood.

The presented study demonstrated that excessive body weight was present in $20 \%$ of the girls 
Gaździńska A. et al. - Assessment of the nutritional...

Tab. 1. Assessment of nutritional status of the OLL candidates by gender and age.

\begin{tabular}{|c|c|c|c|c|c|c|c|c|}
\hline Gender & Age [years old] & Parameter & $\mathbf{N}$ & $\mathbf{x}$ & SD & Me & Min. & Max. \\
\hline \multirow{8}{*}{ Girls } & \multirow{4}{*}{14} & Body height $[\mathrm{cm}]$ & 4 & 167.1 & 3.0 & 167.3 & 163.5 & 170.5 \\
\hline & & Body mass [kg] & 4 & 54.2 & 12.2 & 49.6 & 45.6 & 72.1 \\
\hline & & Total body fat percentage [\%] & 4 & 18.7 & 9.3 & 15.9 & 11.4 & 31.8 \\
\hline & & Skeletal muscle mass $[\mathrm{kg}]$ & 4 & 23.7 & 3.2 & 23.8 & 19.8 & 27.4 \\
\hline & \multirow{4}{*}{15} & Body height $[\mathrm{cm}]$ & 11 & 165.4 & 5.7 & 165.0 & 156.0 & 178.5 \\
\hline & & Body mass [kg] & 11 & 57.4 & 6.4 & 59.5 & 45.6 & 65.9 \\
\hline & & BMI $[\mathrm{kg} / \mathrm{m} 2]$ & 11 & 21.0 & 2.4 & 21.5 & 18.3 & 25.8 \\
\hline & & Total body fat percentage [\%] & 11 & 26.2 & 6.1 & 26.4 & 19.1 & 40.7 \\
\hline \multirow{8}{*}{ Boys } & \multirow{5}{*}{14} & Body mass [kg] & 25 & 57.9 & 10.7 & 57.2 & 37.7 & 77.3 \\
\hline & & BMI $[\mathrm{kg} / \mathrm{m} 2]$ & 25 & 19.6 & 2.5 & 19.5 & 14.4 & 24.1 \\
\hline & & Total body fat percentage [\%] & 25 & 11.9 & 6.0 & 12.4 & 3.0 & 25.3 \\
\hline & & Skeletal muscle mass [kg] & 25 & 28.3 & 5.7 & 27.7 & 16.8 & 38.2 \\
\hline & & Total body water [l] & 25 & 37.4 & 6.9 & 36.8 & 23.7 & 49.6 \\
\hline & \multirow{3}{*}{15} & Body height [cm] & 63 & 174.5 & 5.6 & 174.0 & 158.5 & 186.5 \\
\hline & & Body mass [kg] & 63 & 61.7 & 9.5 & 60.3 & 43.1 & 84.7 \\
\hline & & BMI $[\mathrm{kg} / \mathrm{m} 2]$ & 63 & 20.2 & 2.6 & 19.9 & 15.5 & 27.8 \\
\hline
\end{tabular}

Where: $\mathrm{N}$ - number, $\mathrm{X}$ - mean value, SD - standard deviation, Me - median, Min - minimum, Max - maximum

and $11.3 \%$ of the boys, of which obesity affected $6.7 \%$ and $1.1 \%$, respectively. There were $12.6 \%$ of candidates in the group at risk of underweight and underweight. They were mostly boys.

Other observations were made by Carbos et al. [2] among schoolchildren of pubertal age (11-15 years) in Warsaw, where the percentage of underweight participants ranged from $6.4 \%$ to $9.4 \%$ for boys and from $13.6 \%$ to $14.3 \%$ for girls, depending on the year of study. In contrast to own research, in all studies the frequency of deficient body mass among girls was higher than among boys, and in 2005-2006 it was more than twice as high (13.9\% vs. $6.4 \%$ ).

It is worth to stress that long-term energy-protein malnutrition during puberty may become the cause of pubertal disorders, and significant protein deficiency in childhood may contribute to delayed intellectual development. Nutritional deficiencies may consequently lead to cognitive and emotional disturbances, excessive irritability, and, among other consequences, deterioration of physical fitness as a result of reduction of muscle mass, so undesirable among future OLL students [8].
A higher percentage of children with malnutrition (16\%) was also reported by Wolańska [22] in a group of 13-15 year olds from the Sanok district - the author observed excessive body weight in a higher percentage of adolescents compared to the study discussed in this paper (18\% vs. $12.6 \%)$.

Among Kraków children at the age of 14 the percentage of overweight was at a similar level to that of the OLL candidates and amounted to $12 \%$ in boys and $13.8 \%$ in girls. Obesity was significantly more frequent and amounted to $12.4 \%$ and $12.3 \%$, respectively [16].

Sawicka et al. observed a similar percentage of children with normal body weight and overweight among junior high school students from Educational Facilities in Lublin, Ciecierzyn and Krasienin as in own study - $79 \%$ vs. $74.8 \%$ and $10 \%$ vs. $10.7 \%$, respectively. More obese children were diagnosed ( $9 \%$ vs. $1.9 \%$ ) [18].

A similar percentage of underweight children was reported by Kolmaga et al. among students of post-primary schools in Łódź (3.6\% of girls, $2.6 \%$ of boys) [9]. Overweight in girls from Łódź schools was reported at the same level as in the OLL candidates (13.2\% vs. $13.3 \%)$. Among boys, students 
from Łódź schools were overweight more often (17.9\% vs. $10.2 \%)$. Obesity was diagnosed in a lower percentage of girls from Lodz schools $(2.4 \%$ vs. $6.7 \%)$, while in the boys' group this percentage was higher ( $9.0 \%$ vs. $1.1 \%)$. Observed by the authors of the above study was also an abnormal body composition in most of the students. This concerned high body fat content in $52.2 \%$ of the total number of participants and insufficient content of water in $59.6 \%$ of them. The mean body fat content in the girls participating in the study was $27.2 \%$, which was $3 \%$ higher than among female OLL candidates. The mean body fat content in the boys' group was $17.4 \%$, which was $5.7 \%$ higher than among male OLL candidates.

In the study carried out on 947 students of junior high schools in Białystok, aged 13-15 years, normal body weight was found at a similar level as in own study (in $68.1 \%$ of girls and in $73 \%$ of boys). A higher percentage of underweight $(4.8 \%$ vs. 0 ) and overweight (17.2\% vs $13.3 \%$ ) girls was observed, and there were more obese individuals in the boys' group compared to own study $(11.7 \%$ vs. 1.1\%) [20].

In a nationwide study conducted under the OLAF program in 2007-2009 ona population of children and adolescents aged 7-18 years, it was shown that $8.7 \%$ of boys and $13.0 \%$ of girls were underweight, $14.4 \%$ of boys and $11.1 \%$ of girls were overweight, and $4.8 \%$ of boys and $2.5 \%$ of girls were obese [11]. Looking at age and gender, the prevalence of overweight among boys ranged from $10.7 \%$ at age 14 to $16.9 \%$ at age 12 , while among girls it was between $7.1 \%$ at age 18 and $17 \%$ at age 9 . Obesity affected boys aged 8 and 10 (5.9\% each) more often than boys aged $16(2.3 \%)$, and similarly - girls aged 8 (4.5\%) more often than girls aged 16 (1.1\%).

The results of this study on the nutritional status of OLL candidates, compared to the results of the nutritional status of adolescents of a similar age presented by other authors, showed a lower percentage of overweight and obesity in the group of boys.

\section{CONCLUSIONS}

The majority of the OLL candidates examined were of normal body weight.

No significant differences were noted between the nutritional status and the gender of the participants, based on BMI.

Overweight and obesity diagnosed on the basis of body fat percentage was significantly more frequent in the group of girls.

There is a need to educate youth about the health consequences of abnormal body weight, both underweight and overweight.

\section{AUTHORS' DECLARATION:}

Study Design: Agata Gaździńska, Paweł Jagielski. Data Collection: Agata Gaździńska, Marta Turczyńska. Manuscript preparation: Agata Gaździńska, Marta Turczyńska, Paweł Jagielski. The Authors declare that there is no conflict of interest.

\section{REFERENCES}

1. Bryl W, Hoffmann K, Miczke A, Pupek-Musialik D. Otyłość w młodym wieku - epidemiologia, konsekwencje zdrowotne, konieczność prewencji. Przew Lek 2006; 9: 91-95.

2. Chabros E, Charzewska J, Wajszczyk B, Chwojnowska Z. Częstość występowania niedoborowej masy ciała u młodzieży warszawskiej w wieku pokwitania w ostatnich 3 dekadach. Probl Hig Epidemiol 2011; 92(1): 99-102.

3. Freedman DS, Mei Z, Srinivasan SR et al. Cardiovascular risk factors and excess adiposity among overweight children and adolescents: The Bogalusa Heart Study. J Pediatr 2007;150: 12-17.

4. Gaździńska A, Baran P, Skibniewski F, Truszczyński O, Gaździński S, Wyleżoł M. Częstość występowania nadwagi i otyłości u studentów lotniczej uczelni wojskoweja poziom ich aktywności fizycznej. Medycyna Pracy 2015; 66(5): 653-66.

5. Gaździńska A, Kłossowski M. Ocena wpływu wybranych czynników żywieniowych oraz aktywności fizycznej na występowanie nadwagi i otyłości u wojskowego personelu latającego. Polski Przegląd Medycyny Lotniczej 2006; 12(2): 125-135. 
6. Kasley MM, Zaepfel AA, Bjornstad P, Nadeau KJ. Age-related consequences of childhood obesity. Gerontology 2014; 60: 222-228.

7. Kędzior A, Jakubek-Kipa K, Brzuszek M, Mazur A. Trendy w występowaniu nadwagii otyłości u dzieci na świecie, w Europie i w Polsce, Endokrynol Ped 2017.16.1.58: 41-48.

8. Klemarczyk W. Różne aspekty problemu niedożywienia dzieci w Polsce. In: Niedożywienie dzieci w Polsce - na drodze do skutecznego rozwiązywania problemu. Opening report. Danone 2007: 7-8.

9. Kolmaga A, Zimna-Walendzik E, Łaszek M, Niedźwiedzka-Stadnik M, Trafalska E, Szatko F. Ocena stanu odżywienia 16-letniej młodzieży z łódzkich szkół ponadpodstawowych. Probl Hig Epidemiol 2014; 95(1): 93-97.

10. Kułaga Z, Litwin M, Tkaczyk M, et al. Polish 2010 growth references for school-aged children and adolescents. Eur J Pediatr 2011; 170(5): 599-609.

11. Kułaga Z, Litwin M, Zajączkowska MM, Wasilewska A, Tkaczyk M, Gurzkowska B, Świąder A, Różdżyńska A, Napieralska E, Grajda A, Barwicka K. OLAF Research Team. Regionalne różnice parametrów antropometrycznych oraz ciśnienia tętniczego uczniów w wieku 7-18 lat. Probl Hig Epidemiol 2009; 90(1): 32-41.

12. Kułaga Z, Różdżyńska A, Palczewska I et al. Siatki centylowe wysokości, masy ciała i wskaźnika masy ciała dzieci i młodzieży w Polsce - wyniki badania OLAF. Standardy Medyczne, Pediatria 2010; 7: 690-700.

13. Litwin SE. Childhood obesity and adulthood cardiovascular disease: quantifying the lifetime cumulative burden of cardiovascular risk factors. J Am Coll Cardiol 2014; 64: 1588-1590.

14. Malczyk E. Stan odżywienia dzieci i młodzieży w Polsce na podstawie piśmiennictwa z ostatnich 10 lat (2005-2015). Ann Acad Med Siles 2016; 70: 56-65.

15. McCarthy HD, Cole TJ, Fry T, et al. Body fat reference curves for children. Int J Obes 2006; 30(4): 598-602.

16. Mleczko E, Szmigiel Cz. Otyłość i nadwaga dzieci i młodzieży z Krakowa na tle wyników badań rówieśników z innych populacji. Antropomotoryka 2011; 51: 81-98.

17. Rolland-Cashera MF, Deheerger M, Bellisle F, Sempe M et al. Adiposity rebound in children a simple indicator for predicting obesity. Am J Clin Nutr 1984; 39: 129-135.

18. Sawicka KM, Wawryniuk A, Łuczyk RJ, Krzyżanowska E, Szubiela N, Łuczyk M, Daniluk J. Ocena stanu odżywienia i sposobu żywienia dzieci uczęszczających do szkół podstawowych i gimnazjalnych, Journal of Education, Health and Sport 2017; 7(7): 510-528.

19. Sielużycka A. Metody oceny stanu odżywienia dzieci i młodzieży. Pediat Pol 2010; 85(4): 394-398.

20. Stefańska E, Falkowska A, Ostrowska L. Ocena sposobu żywienia młodzieży gimnazjalnej miasta Białegostoku o zróżnicowanym stopniu odżywienia. Rocz Państ Zakł Hig 2012; 63(4): 469-475.

21. WHO. Obesity and overweight 2016.

22. Wolańska D. Ocena sposobu żywienia młodzieży w wieku 13-15 lat z terenów wiejskich w aspekcie zagrożenia chorobami żywieniowozależnymi w wieku dorosłym. Gastroenterologia Polska 2018(4):141-146.

23. Xie B, Chou Ch, Spruijt-Metz D, Reynolds K, Clark F, Palmer PH, Gallaher P, Sun P, Guo Q, Johnson CA. Weight Perception, Academic Performance, and Psycho-logical Factors in Chinese Addoloscent, American Journal of Health Behavior 2006; 30 : 115-124.

Cite this article as: Gaździńska A, Turczyńska M, Jagielski P. Assessment Of The Nutritional Status Of Candidates To The Aviation High School In Dęblin. Pol J Aviat Med Bioeng Psychol 2019; 25(3): 15-21. DOI: 10.13174/pjambp. 19.05.2021.02 